\title{
Editorial
}

\section{Serum Cholesterol and Nutrition in Japan}

The relationship between hypertension and other risk factors of coronary heart disease, particularly serum lipid levels has been an important medical problem through the world.

It has been well-known that the incidence of myocardial infarction among Japanese people was lower than those in western countries. By epidemiologic and nutritional studies, the fact was referred partly to the low serum cholesterol levels among Japanese, which can be attributable to Japanese dietary habits.

During the past few decades, however, the incidence of coronary heart disease in Japan has been increasing.

Comparably, we made sequential observations of serum lipid levels of a large number of Japanese people over the past twenty years. In 1961, the average cholesterol level, studied in 6,977 normal subjects, was $176 \mathrm{mg} / \mathrm{dl}$.

The second survey, made in 1970 on 3,555 subjects, revealed that the averages were $185 \mathrm{mg} / \mathrm{dl}$ for men and $187 \mathrm{mg} / \mathrm{dl}$ for women.

The third survey, conducted from 1980 to 1981 on 10,977 subjects, demonstrated that the mean cholesterol level increased to $190 \mathrm{mg} / \mathrm{dl}$ for men and $192 \mathrm{mg} / \mathrm{dl}$ for women. Namely, an increase of approximately $15 \mathrm{mg} / \mathrm{dl}$ occurred during the last twenty years.

For comparison, the serum cholesterol levels of American men and women were much higher than that of Japanese in 1972, but the levels of American people younger than thirty years old was much lower than that of Japanese of comparable age. It has been known that diet is an important factor, related to serum cholesterol level.

Although the total caloric intake of Japanese people remained unchanged over the past twenty years, their dietary habits have changed markedly.

The intake of dietary fat in Japan became more than double at present (from $26 \mathrm{~g}$ to $55 \mathrm{~g}$ per day), and it accounts for 23 percents of the total calories. The intake of animal protein also increased 1.6 times (from $25 \mathrm{~g}$ to $39 \mathrm{~g}$ ), which counts for 15 percents of the total calories.

In addition, there has been a trend, particularly among young Japanese, that the fish was not a primary source of animal protein any more in recent years. These changes of dietary habits may be considered, at least in part, to be responsible for the rise in serum cholesterol level among Japanese.

I am afraid that the incidence of ischemic heart diseases in Japanese might increase within ten or twenty years, and that it may be due to increasing serum cholesterol level. Therefore, it should be recommended to change dietary habits particularly to young Japanese people.

\section{Yuichiro Goто}

Professor of Medicine,

Tokai University School of Medicine, Isehara 